\title{
THE EFFECTS OF IRON TABLET PROGRAM, INTRAPERSONAL, AND SOCIAL FACTORS ON NUTRITION INTAKE TO PREVENT ANEMIA IN FEMALE ADOLESCENTS IN YOGYAKARTA
}

\author{
Ailsa Clarissa Cynara'), Eti Poncorini Pamungkasari²), Bhisma Murti1) \\ 1)Masters Program in Public Health, Universitas Sebelas Maret \\ 2)Faculty of Medicine, Universitas Sebelas Maret
}

\begin{abstract}
Background: Complexity of behavior among adolescents and the effects of various factors on their behavior require a deeper vision on their health-related behavior components. Inadequate intake of calcium-rich foods and low intake of essential vitamins among female adolescents are cases that indicate the need for a change in the feeding behavior among them. This study aimed to examine the effects of iron tablet program, intrapersonal, and social factors on nutrition intake to prevent anemia in female adolescents.

Subjects and Method: A cohort retrospective study was carried out in Senior High Schools in Yogyakarta, Indonesia. A sample of 120 female adolescents was selected by purposive sampling. The dependent variable was nutrition intake. The independent variables were iron tablet program, perceived susceptibility, perceived seriousness, and perceived benefit, and family income. The data were collected by questionnaire and analyzed by a multiple logistic regression.

Results: Nutrition intake to prevent anemia in female adolescents increased with iron tablet supplementation program $(\mathrm{OR}=11.87 ; 95 \% \mathrm{CI}=1.70$ to $82.76 ; \mathrm{p}=0.013)$, high family income $(\mathrm{OR}=24.76 ; 95 \% \mathrm{CI}=1.96$ to $313.22 ; \mathrm{p}=0.013)$, high perceived susceptibility $(\mathrm{OR}=$ $77.88 ; 95 \% \mathrm{CI}=4.12$ to $1471.73 ; \mathrm{p}=0.004)$, high perceived seriousness $(\mathrm{OR}=228.46 ; 95 \%$ $\mathrm{CI}=7.08$ to $7369.90 ; \mathrm{p}=0.002)$, and high perceived benefit $(\mathrm{OR}=94.72 ; 95 \% \mathrm{CI}=4.87$ to 1841.55; $\mathrm{p}=0.003)$. Nutrition intake decreased with high perceived barrier $(\mathrm{OR}=0.02$; $95 \% \mathrm{CI}=0.01$ to $0.40 ; \mathrm{p}=0.010$ ).

Conclusion: Nutrition intake to prevent anemia in female adolescents increases with iron tablet program, high family income, high perceived susceptibility, high perceived seriousness, and high perceived benefit. Nutrition intake decreases with high perceived barrier.
\end{abstract}

Keywords: anemia, iron tablet, intrapersonal factor, health belief model

\section{Correspondence:}

Ailsa Clarissa Cynara. Masters Program in Public Health, Universitas Sebelas Maret. Jl. Ir. Sutami 36A, Surakarta 57126, Central Java. Email: ailsaclarissacynara@student.uns.ac.id. Mobile: 082230233293. 